\title{
Institutionalized Care and Child Wellbeing: A Study of Residents of Child Welfare Institutions of District Sargodha
}

\author{
Aaqib Shahzad Alvi \\ Department of Social Work \\ University of Sargodha \\ Asif Naveed Ranjha \\ Department of Social Work \\ The Islamia University of Bahawalpur \\ Ibad Ullah Sajid \\ Social Welfare \& Bait ul Mall Department Rawalpindi
}

\begin{abstract}
This research has focussed on child welfare services and wellbeing among residents of residential child care centres. A well designed interview schedule and a wellbeing scale were used as instruments. The purposive sampling technique was used from the target population and 115 respondents were taken as sample size. Analysis of the data was made on the basis of descriptive analysis and Cross- tabulation. Results reveal that two third of respondents were male. It has also found that majority of respondents reported positively regarding staff behaviour, living arrangements, nutrition status, arrangements of education and health condition. Moreover, almost half of the children have moderate and one forth estimated high level of wellbeing. A plethora of children desired to live in these institutions because they fulfil their basic needs. Majority of residents of Kashana, Anjumane-e-Khaliqia were belonged to rural areas and SOS Village residents were residents of urban community. Most of Kashana residents had both parents alive whereas in other child care centres majority were orphans. No significant variation was observed regarding levels of satisfaction in these three institutions. Hence, these institutions play a vital role in upbringing, child welfare services and wellbeing of orphans and vulnerable.
\end{abstract}

Keywords: Residential Child Care Centres/institutions, Wellbeing, Orphans, Institutionally Reared Children.

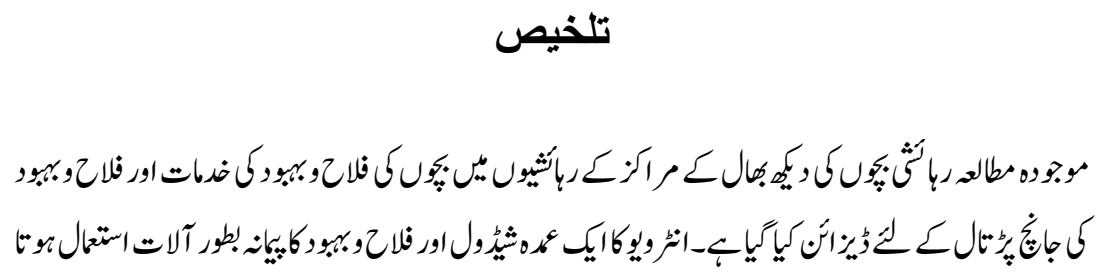




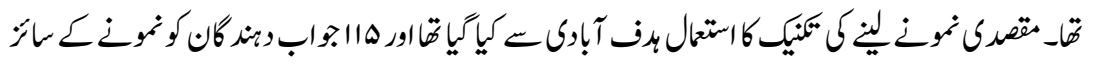

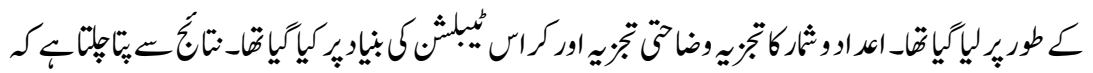

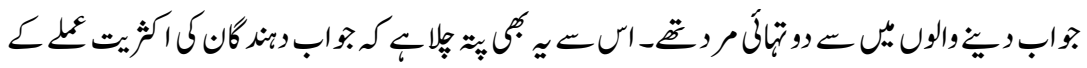

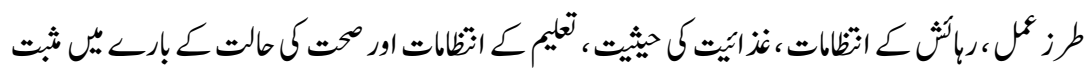

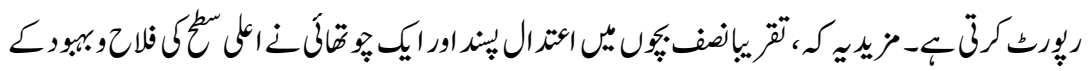

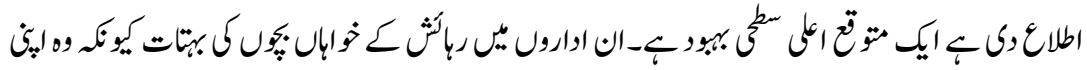

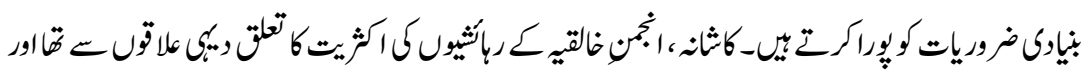

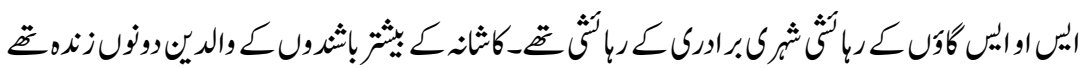

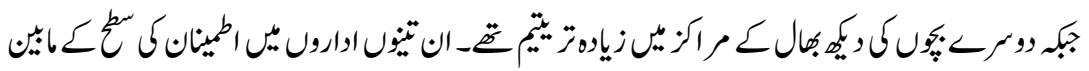

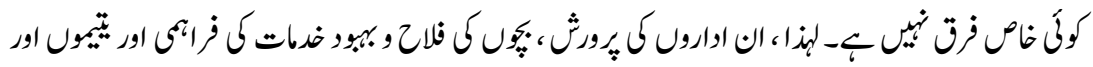

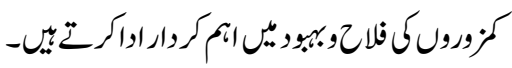

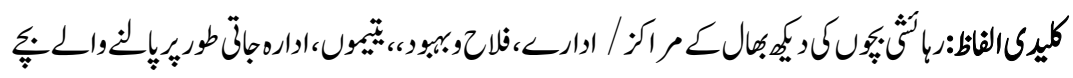

\section{Introduction}

Around the world, children's' homes attempt to focus on the issues of vagrants, destitute, helpless ones who are powerless and battle to think about themselves freely. Without the supporting, direction, and assets that guardians give, these kids have various needs and they are unable to accommodate themselves. Children are crucial resource and eventual fate of the country. Society ought to give the chance to their appropriate mental, physical and moral development and character improvement that adds to their prosperity and wellbeing.

Gillings, Steele, and Hynes (2015) estimate eight million children living in care institutions around the world. More than 80 percent of them are having living guardians and the larger part could be brought together with families provided the correct help. Stranded, destitute and other unaccompanied kids and children frequently alluded to universally as vagrants and weak kids, or orphan and vulnerable children speak to a noteworthy yet inadequately spoke to worldwide populace. UNICEF gauges that there are around 153 million orphans around the world (UNICEF, 2015). Moreover, working for healthy lives and expanding welfare at all age levels is important for sustainable development goals in current scenario.

In preview of Millennium Development Goals, the child survival and flourishment are both recognized as important global aims. Recently, the importance of child 
hood experience has been merged with the evidence base long term and short term conclusions (Black \& Hurley, 2016; Dua et al., 2016). These results cross a broad range of accomplishment regarding education, employment, wellbeing, intergenerational parenting, and mental health of children. However, the advancements in cognitive sciences proved the importance of childhood development and brain cells proliferation in early years (Phillips \& Shonkoff, 2000).

UNICEF considers an "Orphan" a kid having age under 18 years who has lost one or both parents (death of parents). He/she may be single orphan or twofold orphan. Almost 125 million children became single orphans and 15.1 million kids lost both parents (UNICEF, 2017). There are 4 million of orphans in Pakistan (Sayyid, 2015). As indicated by the Situational Analysis of Children in Pakistan, 2017 Pakistan has $39 \%$ of populace under 18 years.

Understanding of 'Institution' is with reference to children a care centre with services for more than ten children having no guardians are provided by paid professional careers. Private consideration infers a sorted out, everyday practice and indifferent (Browne, 2017). Petrowski, Cappa, and Gross (2017) reported that that almost 2.7 million children were having institutional care services in spite of the fact that the nature of accessible information from numerous nations was poor and the same number of such care centres were unregistered with no official and authentic data of children. The UN appraises the institutional care and living of 8 million children in private organizations. Majority of these kids have families but get care from private institutions for reasons of neediness.

In Pakistan, few children are joined up with Child Care Centres (CCs) in light of the fact that their essential parental figures are not, at this point alive, yet there are numerous others reasons. If there should be an occurrence of parental separation or partition, guardians get themselves incapable to bring up their children properly. Majority of them flee from homes as a result of residential or school viciousness and end upon boulevards and other open spots where from they are joined up with some halfway house or child care centres.

In Islam, the wellbeing of children especially orphans and vulnerable children have been emphasized. Prophet Mohammad (Peace Be Upon Him) was himself an orphan. There is incredible significance set in the Quran and Sunnah (the lessons of the Prophet (PBUH) in the treatment of the helpless and orphan children. "Prophet Mohammad (PBUH) said, "I and the individual who takes care of a vagrant and accommodates him, will be in Paradise like this," putting his list 
and center fingers together. - Narrated by Sahl canister Sa'd" (Sahih al-Bukhari 6005, Hadith 34).

Child wellbeing is a multifaceted and holistic approach that deals with health, education, living conditions and housing, interpersonal relationship, and material wellbeing. It focused the quality of life and happiness of the child in the front position and aims at enhancing the capabilities of the child in accordance with the basic indicators in each domain. Wellbeing is concerned with self realization and creating conditions that are important for enhancing the current and future capacities of children. Therefore at national and international level efforts should be made to improve these indicators of wellbeing (Semerci \& Erdoğan, 2014).

Material products (lodging structure, web, quality garments for attending class), social articles (books, papers) in their access, social relationships and security have impact on wellbeing of children (Casas, Bello, Gonzalez, \& Aligué, 2012). There is a typical saying that "children are future of a country." Consequently, the degree of care and consideration kids get is extremely applicable. Truth be told, most writers have composed that if children are all around thought about, they will develop to become valuable residents. So it's essential for guardians to give the essential love and consideration for their physical and mental wellbeing.

In Pakistan, Social safety net is a multi-faceted discipline in its wider functions and objectives. It serves to the welfare of poor, disabled, impoverished, economically and socially oppressed children and adolescents of community. Children Homes (Orphanages), Chaman "centre for the treatment \& rehabilitation of mentally retarded children", Neghaban "for the lost, kidnapped and runaway children", Kashana "for poor needy and orphan female children" and Gehwara "Abandoned babies and destitute children Home" are the projects operating by social protection sectors for the rehabilitation and welfare of orphaned and needy children of society. These institutions have serious concerns for increasing the wellbeing services for children (Punjab Portal, 2020).

Kashana is rendering welfare services to female children, working under the "Department of Social Welfare \& Bait ul Maal, Government of the Punjab". In Kashana, the government provides food as well as boarding and education facilities under the supervision of social welfare officer and the subordinate staff who look after them around the clock. SOS (Save our Soul) Children's Villages provide welfare services for children including boarding lodging, family bonding and other services like natural family (SOS Children's Villages Pakistan, n.d.). 
It provides family environment for these vulnerable and needy children as ecological plays important role in child wellbeing. The Anjumane-e-Khaliqia provides food as well as boarding and education facilities to orphans children. The association is composed of Muslim intellectuals and positions seeking to reform Muslim society and work on its development.

Children are hopes, future, aspiration and undoubtedly the most valued asset of any nation. Children are considered in Pakistani culture as a gift by the Almighty Allah. Despite many achievements, we still have many gaps to fill regarding child rights in the country. We have to do lot of work especially for children those victims of social exclusion, abandoned and abused or exploited by families or the community. Children with disabilities and female are at higher risk comparatively. In this world, many children are considered to be difficult in the perspective of the western world. In the current study sample has been taken from three institutions i.e. Kashana, SOS village and Anjumane-e-Khaliqia and both are nongovernmental organizations.

This study is to explore the child welfare services and wellbeing of Children residing in the welfare institutions/ centres in Punjab, to gain knowledge on their well-being as well. There is no reliable data or research conducted in Pakistani context, where wellbeing of children residing in Institutional care centres could be researched and addressed. This research will be valuable for devising strategies for future interventions for child welfare and wellbeing at institutional level and build the capacity of the children leading to age 18 years to aid their reintegration into society.

\section{Review of Literature}

The UNCRC "United Nations Convention on the Rights of the Child" promoted and protected children worldwide and as the world's most broadly accepted child welfare treaty. UNCRC clearly emphasises on the rights of children that "all children have a right to education, healthcare, social security, physical care, family life, play, recreation, culture and leisure, and adequate standards of living". All these variables are collectively contribute in the wellbeing of children (UNICEF, 2006).

Lassi, Mahmud, Syed, and Janjua (2011) discussed a comparison of Children's behavioural issues in institution SOS Village and in conventional institutions for orphans. It was reported that conventional institutions were having more younger children than SOS village institutions. Children's stay at conventional institutions was shorter in comparison to stay in SOS village. SOS village institutions were having higher number of children in age appropriate classes while other conventional institutions had lower number. 
Garvin, Tarullo, Van Ryzin, and Gunnar (2012) reported that social isolation and less communication skills were witnessed in children. A very limited number of child residents in orphanage were social interaction in society. It is evident from other writings too that orphanages' residents have low level of social interaction and capacities to handle routine social relationship matters.

According to Khalid (2006), for children, substitute care other than the umbrella of family support has been a neglected field that has had long-lasting effects on the healthy growth of the youngster in the country. Consequences of this ignoring attitude themselves in increasing number of children in the street, involved in crime, begging, and exposed to all forms of exploitation, including sexual abuse. Children under age of 14 years make $45 \%$ of the total population in Pakistan. Even on the basis of the numbers, it is necessary that the child should provided care by the state in order to protect and to advance the human capital, because peace and prosperity of the country eventually depends upon the human capital.

Khan, Khan, and Majeed (2014) presented a study with the objective to probe the personality variation between the orphans those living in the institutions, non institutionalized orphans, and thirdly the non orphan adolescence. Results of a study clearly show impact difference regarding hostility and world view among children i.e., orphan children in institutions, orphan children having non institutionalized services and normal children (not orphans). It was shown that there was less difference in dependency, self-esteem, self adequacy, emotional responsiveness and emotional stability among all three groups included in research. Another research pointed out welfare of orphans in relation to psychological aspects in China which explained that level of psychological wellbeing of orphans is low in comparison to children with families (Chi, $\mathrm{Li}$, Barnett, Zhao \& Zhao, 2014). Tsegaye (2013) reported the same thing that the ratio of psychological wellbeing is comparatively low in orphan children than the non orphans.

Whetten et al. (2014) carried out a study entitled "A Comparison of the Wellbeing of Orphans and Abandoned Children Ages 6-12 in institutional and community based care setting". The study indicated that situation of orphans in care institutions was not bad in comparison to orphans living in community regarding health, physical development, emotional and psychological functioning. In this way, hypothesis of better care of community care in comparison to institutional care was not supported in those nations where child care is a big problem. Another study reported contrast to the results presented by Whetten et al. that reported various types of difficulties would be encountered by vulnerable children 
rather than normal children residing in community setting with families. With regard to the development context, the study results exposed that children residing in the institutions had more negative impact than the children with families. Conversely, with regard to the life satisfaction and positive affects, no significant difference was observed between these orphan children and those living with the families (Poletto \& Koller, 2011).

According to the review of previous studies (Berens \& Nelson, 2015; Johnson, Browne \& Hamilton-Giachritsis, 2006; Van Ijzendoorn, Luijk, \& Juffer, 2008), the optimal child development has been ensued in family system rather than institutional setting. Similar findings were also presented by Van IJzendoorn et al. (2011), they revealed that children's of care centres had to face structural neglect including minimal physical resources, challenging staffing patterns and lack of interaction with caregivers.

Akram, Anjum, and Akram (2015) did a cross-sectional study to observe the environmental impact on the growth of orphan and their accomplishment. The socio-economic position of orphans with regard to the role of the institution was also focused. The geographical universe of the study was three SOS children's villages at Lahore, Faisalabad and Multan. It depicts that almost half of the respondents (49.6\%) confirmed that better quality food was being provided in the SOS village while about $27 \%$ and $23 \%$ were agreed a little and disagreed with the statement, respectively. Food is essential for each, but it is more important for children because they have to grow as a healthy adult in future. More than half $54.4 \%$ of the respondents were of the view that Save for Soul is rendering apposite educational facilities. Almost half of them were satisfied to great extent with health facilities and were satisfied to some extent with the recreational facilities.

Schütz, Castellá Sarriera, Bedin, and Montserrat (2015) conducted a research to evaluate and compare the subjective wellbeing of the children those residing in the welfare homes and; the children residing with the parents and families at home. Sample size of the study was 218 children with the age group of 8 to 12 years. (Mean age was 10.06 and SD was 1.40). Equal sample portion was taken from each category $(50 \%$ from institutions and 50\% from those living with families). Results exhibited that that variables slightly discriminated towards respondents residing at home with the family. It was argued that distinctions may be associated to the evolution and experiences before institutionalization. Many children having some changes are in position keep social connections better and consistent which leads to their wellbeing.

Another research was conducted by Saraswat and Unisa (2017) focusing orphans and children in institutions in India. It was to investigate in-depth the issues of 
understanding the psychosocial worries among orphan and vulnerable children (OVC) residing in residential care homes. The results reported that children had been provided all the basic needs and necessities including boarding, lodging and clothing facilities. They were provided with proper education and medical facilities at the time of need. Results further exposed that the children were really happy and thankful for provision of basic requirements and facilities at institutions as they were deprived of these all basic necessities while living with the families because their parents were unable to bear the expenses. Fulfilment of basic life necessities and availability of facilities relieved poor vulnerable children form routine sufferings. These children were looking optimistic and confident that the education received at the institutions/ orphanage would definitely lead them towards a bright future and prosperity.

Khurshaid, Mahsood, and Kibriya (2018) conducted a study on the "prevalence and determinants of behavioural problems among adolescents dwelling in orphanage of District Peshawar, Pakistan". This research was conducted in the orphanages registered with Social Welfare Department. 360 adolescents were sampled through non-probability sampling and both male and female orphans 10 to 19 years old were the respondents in the study. The results of the study found that out of total 334 , about $93 \%$ were male and $7 \%$ female. They estimated $34 \%$ prevalence of behavioural problem with the highest ratio i.e. $25 \%$ conduct problems, $19 \%$ emotion, $18 \%$ peer problem, $8 \%$ hyperactivity and about $3 \%$ prosocial behaviour. The correlation results comparative analysis exhibited that age, gender, type of orphanage and parent's status were indicated significant associated with behavioural problems $(\mathrm{p}<0.05)$. However, behavioural problems had insignificant association $(\mathrm{p}>0.05)$ with duration of institutionalization and age at parents' demise. It was concluded that a elevated load of behavioural problems was gauge among the residents of the orphanage homes of Peshawar District. These determinants of behavioural problems may be taken as focus of intervention to lessen behavioural problems among adolescents living in orphanages.

Nsabimana, Rutembesa, Wilhelm, and Martin Soelch (2019) conducted a research study to measure the impact of the institutionalization on the psychological adjustment of the residents as well as to find out that if having living parents has any additional influence on the children or otherwise? Covariance analysis indicated that institutionalized children were considerably associated with externalizing behavioural issues than children having no institutionalized care. Further, non-orphan children reported more externalizing behaviour issues than orphans, irrespective of this that they are residing in an institutional setting or home setting. In case of Self-esteem, on-orphans residing with families were significantly associated with their wellbeing rather than other. These findings may be supportive when one has to make decision to admit 
the child in a welfare institution, particularly when a child have living parents, and when chalking out supportive and accommodating scheme for children with no parental care.

Shafiq, Haider, and Ijaz (2020) focused on issues of anxiety, sadness, pressure, and decision-making among children having parents and having no parents in Pakistan. They included 300 children in the research. The data were gathered from various orphanage institutions and schools situated in Lahore. The research found that anxiety, depression, and stress were linked positively with decisionmaking. Level of anxiety was higher among girls in comparison to boys. All girls and boys estimated high decision-making. The percentage of anxiety was high among residents of orphanages as compared to live with families. High decision making power was found in both the segments. The study recommended that it is a dire need to create more awareness at public and private orphan homes towards seeking and introducing curative measures for the welfare of the orphans. Second; regular screening to check depression and; psychological care and mental health may be focused during the routine medical check up of the orphans residing in the homes. Third, life skill trainings including stress management, stress and anxiety coping skills, problem solving techniques and skill pertaining to decision making especially in adverse situations.

\section{Methodology}

This cross-sectional study is based on quantitative research methodology. The selected population of present study was such residents who were in Kashana, Anjumane-e-Khaliqia and SOS Village at Sargodha. By using purposive sampling technique data was collected by all children residing in kashana and respondents were those children who were registered in the institutions. Census approach was applied as there were 115 residents in these three institutions. An interview schedule was constructed for the purpose of data gathering regarding socio-economic demographics and services rendered in these child care centres. A 'Children Wellbeing scale-20' was used as well to measure the level of wellbeing. It included 20 items. These items focused on the physical and mental health status, relationships and environment, positive feeling and negative feelings of respondents. A 3-point scale was used to measure the responses i.e. to some extent, yes and no. The response categories were scored like: To Some Extent $=1, \mathrm{Yes}=2$ and $\mathrm{No}=0$. On the basis of 20 items measuring the level of wellbeing, a respondent may have minimum score of 0 and maximum 40. Lower score indicates low level while higher score shows high level of wellbeing among children. The score index of 0 40 was divided into three categories like: $0-13=$ lower level, 14-27=moderate level, 28-40= high level of wellbeing. 


\section{Results and Discussion}

Table: 1

Demographic attributes of whole sample $(\mathrm{N}=115)$

\begin{tabular}{|c|c|c|}
\hline Demographic & Frequency & Percentage \\
\hline \multicolumn{3}{|c|}{ Residential status of respondents regarding institutions } \\
\hline Kashana & 33 & $28.7 \%$ \\
\hline Anjumane Khaliqia & 32 & $27.8 \%$ \\
\hline SOS Village & 50 & $43.5 \%$ \\
\hline \multicolumn{3}{|l|}{ Age } \\
\hline $9-11$ & 50 & $43.47 \%$ \\
\hline $12-14$ & 44 & $38.26 \%$ \\
\hline $15-18$ & 21 & $18.26 \%$ \\
\hline \multicolumn{3}{|l|}{ Gender } \\
\hline Male & 70 & $60.9 \%$ \\
\hline Female & 45 & $39.1 \%$ \\
\hline \multicolumn{3}{|l|}{ Educational Status } \\
\hline Primary & 46 & $40.0 \%$ \\
\hline Middle & 40 & $34.8 \%$ \\
\hline Matric & 29 & $25.2 \%$ \\
\hline \multicolumn{3}{|c|}{ Residential background } \\
\hline Rural & 72 & $62.6 \%$ \\
\hline Urban & 43 & $37.4 \%$ \\
\hline \multicolumn{3}{|l|}{ Do patents are alive } \\
\hline Both & 39 & $33.9 \%$ \\
\hline Mother & 59 & $51.3 \%$ \\
\hline Father & 10 & $8.7 \%$ \\
\hline Both died & 7 & $6.1 \%$ \\
\hline \multicolumn{3}{|c|}{ Occupation of parents } \\
\hline Job & 9 & $7.8 \%$ \\
\hline Labour & 42 & $36.5 \%$ \\
\hline Business & 8 & $7.0 \%$ \\
\hline Nill & 56 & $48.7 \%$ \\
\hline \multicolumn{3}{|c|}{ Monthly income of family } \\
\hline $2000-4000$ & 5 & $4.3 \%$ \\
\hline $5000-7000$ & 22 & $19.1 \%$ \\
\hline $8000-10000$ & 33 & $28.7 \%$ \\
\hline no income & 55 & $47.8 \%$ \\
\hline
\end{tabular}

Table.1 indicates the socio-economic demographics of residents residing in Kashana, SOS and Anjume-Kaliqia in Sargodha. The current study presents glance on a comparison of wellbeing and institutional care among children residing in institutional setting. A sample of 115 respondents was taken. The study 
findings indicate that $43.5 \%$ of respondents were residing in SOS Village and others resided in Kashana and Anjumene Khaliqia. The average age of respondents was 15 years. The ratio of male respondents is higher i.e. $60.9 \%$ as compare to female respondents. Almost half of the children were getting primary education. $62 \%$ were belonging to rural area and remaining was residing in urban community. $33 \%$ of respondents' parents were alive. Almost half of the respondents i.e. $48.7 \%$ did not have any source of income and slightly more than one third were labourer.

Table: 2

Child welfare services and level of satisfaction among residents of residential child care centres

\begin{tabular}{|c|c|c|}
\hline Responses & Frequency & Percentage \\
\hline \multicolumn{3}{|c|}{ Respondents' views regarding treatment level of institutional staff } \\
\hline Polite & 115 & $100 \%$ \\
\hline \multicolumn{3}{|c|}{ How institutional staff treat residents } \\
\hline Junior staff & 57 & $49.6 \%$ \\
\hline Senior Staff & 25 & $21.7 \%$ \\
\hline Both & 33 & $28.7 \%$ \\
\hline Total & 115 & $100 \%$ \\
\hline \multicolumn{3}{|l|}{ Condition of rooms } \\
\hline Airy & 114 & $99.1 \%$ \\
\hline Specious & 1 & $.9 \%$ \\
\hline \multicolumn{3}{|l|}{ Health conditions } \\
\hline Good & 97 & $84.3 \%$ \\
\hline $\mathrm{Bad}$ & 1 & $.9 \%$ \\
\hline Normal & 17 & $14.8 \%$ \\
\hline \multicolumn{3}{|l|}{ Quality of food } \\
\hline Poor & 3 & $2.6 \%$ \\
\hline Good & 100 & $87.0 \%$ \\
\hline Normal & 12 & $10.4 \%$ \\
\hline \multicolumn{3}{|c|}{ Provisions regarding educational facilities } \\
\hline In House Education & 22 & $19.1 \%$ \\
\hline Sent to nearby Govt. School & 65 & $56.5 \%$ \\
\hline Private Schools and Colleges & 28 & $24.3 \%$ \\
\hline \multicolumn{3}{|c|}{ Satisfaction with institutional services } \\
\hline Yes & 112 & $97.4 \%$ \\
\hline No & 1 & $.9 \%$ \\
\hline To some extend & 2 & $1.7 \%$ \\
\hline \multicolumn{3}{|c|}{ Respondents' views regarding stay at institutions } \\
\hline Yes & 32 & $27.8 \%$ \\
\hline No & 83 & $72.2 \%$ \\
\hline
\end{tabular}




\begin{tabular}{|l|c|c|}
\hline Reason to remain attach with institution \\
\hline Emotional Attachment & 20 & $17.39 \%$ \\
\hline Family Environment & 12 & $10.43 \%$ \\
\hline Nill & 83 & $72.17 \%$ \\
\hline Recreational activities of residents & $42.6 \%$ \\
\hline Book reading & 49 & $18.3 \%$ \\
\hline Watch tv & 21 & $39.1 \%$ \\
\hline Playing games & 45 & \\
\hline Future aspirations of residents & $24.3 \%$ \\
\hline Teacher & 28 & $40.9 \%$ \\
\hline Army forces & 47 & $4.3 \%$ \\
\hline Religious scholar & 5 & $12.2 \%$ \\
\hline Doctor/Engineers & 14 & $18.3 \%$ \\
\hline Nothing & 21 & \\
\hline
\end{tabular}

Table.2 depicts the responses of residents about institutional child welfare services among residents of child care centres. In case of behaviour of institutional staff members, all of the children responded positively regarding their dealing in routine matters. Moreover, children were more satisfied with the behaviour of junior staff as compared to senior ones. These finds are in line with previous studies. These results supported the claim that welfare organizations work for the wellbeing of the organization regardless of their characteristics but as per their needs and requirements (Landy \& Conte, 2016). 99.1\% respondent view was that rooms were airy. Numerous studies indicated that the level of wellbeing is reported by the people who live in airy rooms as compared to congested rooms (Jelleyman \& Spencer, 2008). Health condition of $84.3 \%$ respondents was good and satisfactory. In case of food quality $2.6 \%$ respondents say that food was poor, while $87 \%$ respondents say that food was of good quality. This implies the findings of the existing study supported and replicated the previous results about the association of health condition and the wellbeing level among children (Paul et al., 2011). In case of arrangement of education $19.10 \%$ respondents availed in house education facility. While $56.5 \%$ respondents sent to nearby schools and $24.3 \%$ were sent to other private schools and colleges. In case of satisfaction with institutional service, $97.4 \%$ respondents were completely satisfied with institutional services These findings are supported by previous studies as Fazel and co-researchers reported that the majority of the children residing in Kashana were found attending school but there were different arrangements for different children (Fazel, Reed, Panter-Brick, \& Stein, 2012). It was also found that $3 / 4$ of students want to stay in institutions. $28.7 \%$ respondents want to leave institutions because of their emotional attachment with parents and they were desirous to live 
in family setting rather institutional setting. The findings of study show that mostly respondents to take part in outdoor activities to enjoying their lives. Most of the respondents felt clam and peaceful in the institutions. Majority of children were hopeful and optimize about their future life and most of them wanted to join the army, teacher and doctor's profession in future.

Table: 3

Residential status of respondents versus community/ background of residents

\begin{tabular}{|l|c|c|c|}
\hline \multirow{2}{*}{ Institutions } & \multicolumn{2}{|c|}{ Community } & \\
\cline { 2 - 4 } & Rural & Urban & Total \\
\hline Kashana & $21.7 \%$ & $7.0 \%$ & $28.7 \%$ \\
\hline Anjumane Khaliqia & $23.5 \%$ & $4.3 \%$ & $27.8 \%$ \\
\hline SOS Village & $17.4 \%$ & $26.1 \%$ & $43.5 \%$ \\
\hline Total & $62.6 \%$ & $37.4 \%$ & $100 \%$ \\
\hline
\end{tabular}

The cross table is about regarding residential status of respondents regarding community background. It shows that in Kashana 21.7\% Respondents live in rural areas while $7 \%$ live in urban areas and in case of Anjuman E Khaliqia 23.5\% live in rural areas and $4.3 \%$ live in urban areas. In case of SOS Village $17.4 \%$ live in rural areas and $26.1 \%$ live in urban areas. It shows that most respondents belong to rural areas that are $62.6 \%$. It indicates that in Kashana and Anjumane-eKhaliqia majority of the respondents were belong to rural areas and in SOS Village the respondents of one forth were belong to urban areas.

Table: 4

Cross tabulation between institutions and parents

\begin{tabular}{|l|c|c|c|c|c|}
\hline \multirow{2}{*}{ Institutions } & \multicolumn{4}{|c|}{ Do your parents are alive of Respondents } & \multirow{2}{*}{} \\
\cline { 2 - 6 } & Both Alive & $\begin{array}{c}\text { Mother } \\
\text { Alive }\end{array}$ & $\begin{array}{c}\text { Father } \\
\text { Alive }\end{array}$ & $\begin{array}{c}\text { Both } \\
\text { Died }\end{array}$ & Total \\
\hline Kashana & $16.5 \%$ & $10.4 \%$ & $0.9 \%$ & $0.9 \%$ & $28.7 \%$ \\
\hline $\begin{array}{l}\text { Anjumane } \\
\text { Khaliqia }\end{array}$ & $4.3 \%$ & $23.5 \%$ & $0.0 \%$ & $0.0 \%$ & $27.8 \%$ \\
\hline SOS Village & $13.0 \%$ & $17.4 \%$ & $7.8 \%$ & $5.2 \%$ & $43.5 \%$ \\
\hline Total & $33.9 \%$ & $51.3 \%$ & $8.7 \%$ & $6.1 \%$ & $100 \%$ \\
\hline
\end{tabular}

This cross tabulation is about alive status of parents of respondent either they alive or not. In case of kashana $16.5 \%$ of people have both parents alive, $10.4 \%$ peoples mothers alive, 0.95 people have fathers alive and $0.9 \%$ have both died. In 
case of Anjuman e khaliqia 4.3\% people have both parents alive, 23.5\% peoples mothers alive, $0 \%$ peoples fathers alive and $0 \%$ have mothers alive. In respect to SOS Village $13 \%$ people have both parents alive, mothers of $20 \%$ people are alive and $7.8 \%$ respondents' fathers are alive and $5.2 \%$ peoples have both parents died In total percentage results shows that most respondents are orphan because their fathers were died. Most respondents of Kashana have both parents alive which majority of respondents in Anjumane-e-Khaliqia were orphan because their father were died.

Table: 5

Comparison of satisfaction level between residents of three institutions

\begin{tabular}{|l|c|c|c|c|}
\hline \multirow{2}{*}{ Institutions } & \multicolumn{2}{|c|}{ Satisfaction with Institutional Services } & \\
\cline { 2 - 5 } & Yes & No & To Some Extent & Total \\
\hline Kashana & $28.7 \%$ & $0.0 \%$ & $0.0 \%$ & $28.7 \%$ \\
\hline $\begin{array}{l}\text { Anjumane } \\
\text { Khaliqia }\end{array}$ & $27.8 \%$ & $0.0 \%$ & $0.0 \%$ & $27.8 \%$ \\
\hline SOS Village & $40.9 \%$ & $0.9 \%$ & $1.7 \%$ & $43.5 \%$ \\
\hline Total & $97.4 \%$ & $0.9 \%$ & $1.7 \%$ & $100 \%$ \\
\hline
\end{tabular}

This cross tabulation shows comparison of satisfaction about institutional services. In case of Kashana 28.7\% (33) respondents are satisfied and $0 \%$ are not. In case of Anjuman-e-Khaliqia 27.8\% (32) of total 32 respondent are satisfied with institutional care. In case of SOS Village $40.9 \%$ (47) are totally satisfied, $0.9 \%$ (1) is not satisfied and $1.7 \%(2)$ are satisfied up to some extent of total 50 respondents. All children of the institution were happy about the services in which provide institution. There is no significant difference between the levels of satisfaction in these three institutions. The results reveals that majority of respondents belong to poor class and the residents were enjoying good facilities of education, health, accommodation, nutrition and recreational. Therefore they were happy and satisfied to live in institutions setting. They are availing good boarding and lodging facilities as compared to their home. Their parents belong to poor class and they did not provide satisfactory standard of life even basic necessities of life. 
Table: 6

Level of wellbeing of respondents

\begin{tabular}{|l|c|c|c|c|c|c|}
\hline Wellbeing & \multicolumn{2}{|c|}{ Kashana } & \multicolumn{2}{c|}{$\begin{array}{c}\text { Anjumane-e- } \\
\text { Khaliqia }\end{array}$} & \multicolumn{2}{c|}{ SOS Village } \\
\hline & Frequency & Percent & Frequency & Percent & Frequency & Percent \\
\hline $\begin{array}{l}\text { Lower } \\
\text { Wellbeing }\end{array}$ & 6 & $18.18 \%$ & 7 & $20.0 \%$ & 0 & $0.0 \%$ \\
\hline $\begin{array}{l}\text { Moderate } \\
\text { Wellbeing }\end{array}$ & 19 & $57.57 \%$ & 10 & $31.2 \%$ & 36 & $72 \%$ \\
\hline $\begin{array}{l}\text { Higher } \\
\text { Wellbeing }\end{array}$ & 8 & $24.24 \%$ & 15 & $49.0 \%$ & 14 & $28 \%$ \\
\hline Total & 33 & $100.0 \%$ & 32 & $100.0 \%$ & 50 & $100.0 \%$ \\
\hline
\end{tabular}

This table portrays the wellbeing level among residents in all the three institution (Kashana, Anjumane-e-Khaliqia and SOS village). These results were estimated from the Wellbeing scale by applying non-parametric statistics. The prevalence of wellbeing level among residents of Kashana reveals that more than half of the children i.e. $57.57 \%$ estimated moderate level of wellbeing and $24.24 \%$ exhibited higher level and $18.18 \%$ had lower wellbeing level. In Anjumane-e- Khaliqia, $49.0 \%$ had high wellbeing, $31.2 \%$ moderate and $20.0 \%$ low level of wellbeing. Whereas, among residents of SOS village majority (72\%) were estimated moderate wellbeing and remaining fraction i.e. $28 \%$ had higher wellbeing. The institution wise comparison of wellbeing level depicts that majority Kashana and SOS residents reported moderate level of wellbeing while majority of Anjumanne Khaliqia residents, almost half of them gauged higher level of wellbeing. In SOS village there were no respondent who reported lower level of wellbeing. The results regarding the provision of services and boarding-lodging facilities in child care canters presented high percentage of satisfaction among residents. The level of satisfaction contributes as a major predictor of wellbeing in previous literature. The results estimated with wellbeing scale supports the same findings as well. The previous studies regarding the wellbeing also support our findings, Wellbeing is an end state where the people have all the basic necessities and they live peacefully. As good education, health, accommodation, recreation and life satisfaction are the main indicators of well being that has been positively reported in the current study.

\section{Conclusions}

The study in hand is aimed to investigate the wellbeing and child welfare services among residents of three child residential care centres of Sargodha. The 
current study explored that the majority of the children were ok with the care services in institutions. They were also satisfied from the behaviour of staff in institutions. Majority of children explained moderate level of wellbeing and almost one forth reported higher level of well being. While comparing the wellbeing level among three institutions, the SOS children have higher level of wellbeing in comparison with other institution such as Kashana and Anjummane-Khaliqia. This may be due to the better services level and especially family environment provided by SOS village that has significant association with mental and social wellbeing of residents of child care centres in accordance with previous studies at global level. Majority of children belong to rural community but rural community lack of any child care centre. Most of their needs are being fulfilled i.e. health needs, educational needs, nutrition needs, recreational need and lodging needs. This satisfactory condition has significant association with wellbeing of children which is clear in the main finding of current study.

As majority of children's parents did not have any proper economic source of income and working as unskilled laborers, therefore the government needs to give priority in policy making for provision of employment opportunities and should initiate family welfare schemes for child welfare. As majority of children belong to rural community and all institutions were established in urban areas for the wellbeing of child as comparison to rural areas and that's why government should established more institution in rural areas to provide free residence to homeless and vulnerable children. This study was conducted in one region, so larger sample and intensive studies should be initiated focusing on long term policies, this will help these children communities in improving their physical and emotional development and wellbeing level.

\section{References}

Akram, M., Anjum, F. \& Akram, N. (2015). Role of Orphanages to Uplift the Socio-Economic Status of Orphans Focusing on SOS Children's Villages in Punjab, Pakistan. Mediterranean Journal of Social Sciences, vol.6:3 S2, pp.177-182.

Berens, A. E. \& Nelson, C. A. (2015). The Science of Early Adversity: Is There a Role for Large Institutions in the Care of Vulnerable Children? The Lancet, vol.386:9991, pp.388-398.

Black, M. M. \& Hurley, K. M. (2016). Early Child Development Programmes: Further Evidence for Action. The Lancet Global Health, vol.4:8, pp.e505-e506. 
Browne, E. (2017). Children in Care Institutions. K4D Helpdesk Report. Brighton, UK: Institute of Development Studies, Retrieved on 15, 12-19 from https://opendocs.ids.ac.uk/opendocs/handle/20.500.12413/13208

Casas, F., Bello, A., Gonzalez, M. \& Aligué, M. (2012). Personal Well-Being among Spanish Adolescents. Journal of Social Research \& Policy, vol.3:2, pp.19-45.

Chi, P., Li, X., Barnett, D., Zhao, J. \& Zhao, G. (2014). Do Children Orphaned by AIDS Experience Distress Over Time? A Latent Growth Curve Analysis of Depressive Symptoms. Psychology, Health \& Medicine, vol.19:4, pp.420-432.

Dua, T., Tomlinson, M., Tablante, E., Britto, P., Yousfzai, A., Daelmans, B. \& Darmstadt, G. L. (2016). Global Research Priorities to Accelerate Early Child Development in the Sustainable Development Era. The Lancet Global Health, vol.4:12, pp.e887-e889.

Fazel, M., Reed, R. V., Panter-Brick, C. \& Stein, A. (2012). Mental Health of Displaced and Refugee Children Resettled in High-Income Countries: Risk and Protective Factors. The Lancet, vol.379:9812, pp.266-282.

Garvin, M. C., Tarullo, A. R., Van Ryzin, M. \& Gunnar, M. R. (2012). Postadoption Parenting and Socioemotional Development in Post Institutionalized Children. Development and Psychopathology, vol.24:1, pp.35-48.

Gillings, V., Steele, J. \& Hynes, R. (2015). New Research Project Brings Hope to 8 Million Children in the World's Orphanages. Retrieved on $10^{\text {th }}$ April 2020, from The Atlantic Philanthropies https:/www.atlanticphilanthropies.org/ news/new-research-project-brings-hope-8-million-children-worldsorphanages

Jelleyman, T. \& Spencer, N. (2008). Residential Mobility in Childhood and Health Outcomes: A Systematic Review. Journal of Epidemiology \& Community Health, vol.62:7, pp.584-592.

Johnson, R., Browne, K. \& Hamilton-Giachritsis, C. (2006). Young Children in Institutional Care at Risk of Harm. Trauma, Violence \& Abuse, vol.7:1, pp.34-60.

Khalid, M. (2006). Social Work Theory and Practice. Karachi, Pakistan: Kifayat Academy. 
Khan, M. N. S., Khan, M. A. \& Majeed, R. (2014). A Comparative Study of Personality Differences between Orphans and Non-Orphans of Lahore. Journal of Pakistan Psychiatric Society, vol.11:2, pp.19-22.

Khurshaid, F., Mahsood, N. \& Kibriya, Z. (2018). Prevalence and Determinants of Behavioral Problems among Adolescents Living in Orphanage Facilities of District Peshawar, Khyber Pakhtunkhwa, Pakistan. Khyber Medcal University Journal, vol.10:2, pp.95-100.

Landy, F. J. \& Conte, J. M. (2016). Work in the 21st Century: An Introduction to Industrial and Organizational Psychology, 5th Edition. Hoboken: Wiley \& Sons.

Lassi, Z. S., Mahmud, S., Syed, E. U. \& Janjua, N. Z. (2011). Behavioral Problems among Children Living in Orphanage Facilities of Karachi, Pakistan: Comparison of Children in an SOS Village with those in Conventional Orphanages. Social Psychiatry and Psychiatric Epidemiology, vol.46:8, pp.787-796.

Nsabimana, E., Rutembesa, E., Wilhelm, P. \& Martin Soelch, C. (2019). Effects of Institutionalization and Parental Living Status on Children's SelfEsteem, Externalizing and Internalizing Problems in Rwanda. Frontiers in Psychiatry, vol.10, pp.1-12.

Paul, V. K., Sachdev, H. S., Mavalankar, D., Ramachandran, P., Sankar, M. J., Bhandari, N. \& Osrin, D. (2011). Reproductive Health and Child Health and Nutrition in India: Meeting the Challenge. The Lancet, vol.377:9762, pp.332-349.

Petrowski, N., Cappa, C. \& Gross, P. (2017). Estimating the Number of Children in Formal Alternative Care: Challenges and Results. Child Abuse \& Neglect, vol.70:8, pp.388-398.

Phillips, D. A. \& Shonkoff, J. P. (2000). From Neurons to Neighborhoods: The Science of Early Childhood Development. Washington, DC: National Academies Press.

Poletto, M. \& Koller, S. H. (2011). Subjective Well-Being in Socially Vulnerable Children and Adolescents. Psicologia: Reflexão e Crítica, vol.24:3, pp.476-484.

Punjab Portal. (2020). Social Welfare \& Bait-Ul-Maal- Services. Retrieved on $10^{\text {th }}$ March, 2020 from https://www.punjab.gov.pk/sw_and_bum_services. 
Sahih al-Bukhari 6005, Book 78, Hadith 36, Vol. 8, Book 73, Hadith 34.

Saraswat, A. \& Unisa, S. (2017). A Qualitative Study Examining Psychosocial Distress and Coping Mechanisms among Orphan and Vulnerable Children Living in Institutional Care in New Delhi, India. Journal of Health and Social Sciences, vol.2:2, pp.195-208.

Sayyid, S. A. (2015). Implications of Four Million Orphans in Pakistan. Retrieved from https://intpolicydigest.org/2015/08/26/implications-of-four-millionorphans-in-pakistan/

Schütz, F. F., Castellá Sarriera, J., Bedin, L. M. \& Montserrat, C. (2015). Subjective Well-Being of Children in Residential Care Centers: Comparison between Children in Institutional Care and Children Living with their Families. Psicoperspectivas Individuo Y Sociedad, vol.14:1, pp.19-30.

Semerci, P. U. \& Erdoğan, E. (2014). Defining and Evaluating Child Well Being Domains and Indicators through the Eyes of Children in Turkey. Turkey: UNICEF.

Shafiq, F., Haider, S. I. \& Ijaz, S. (2020). Anxiety, Depression, Stress and Decision-Making Among Orphans and Non-Orphans in Pakistan. Psychology Research and Behavior Management, vol.13, pp.313-318.

SOS Children's Villages Pakistan. (n.d.). SOS Children's Villages. Retrieved on $12^{\text {th }}$ February, 2020, from https://www.sos.org.pk/Person/ChildrenVillages

Tsegaye, A. (2013). A Comparative Study of Psychological Wellbeing between Orphan and Non-orphan Children in Addis Ababa : The Case of Three Selected Schools in Yeka Sub-city By Afework.

UNICEF. (2006). A Simplified Version of the United Nations Convention on the Rights of the Child. In UNICEF (Ed.). New York: UNICEF.

UNICEF. (2015). The State of The World's Children 2015: Reimagin the Future. New York: UNICEF.

UNICEF. (2017). Orphans Retrieved on $14^{\text {th }}$ February, 2020, from https://www.unicef.org/media/media_45279.html 
Van Ijzendoorn, M. H., Luijk, M. P. \& Juffer, F. (2008). IQ of Children Growing Up in Children's Homes: A Meta-Analysis on IQ Delays in Orphanages. Merrill-Palmer Quarterly, vol.54:3, pp.341-366.

Van IJzendoorn, M. H., Palacios, J., Sonuga-Barke, E. J., Gunnar, M. R., Vorria, P., McCall, R. B. \& Juffer, F. (2011). Children in Institutional Care: Delayed Development and Resilience. Monographs of the Society for Research in Child Development, vol.76:4, pp.8-30.

Whetten, K., Ostermann, J., Whetten, R. A., Pence, B. W., O'Donnell, K., Messer, L. C., \& Thielman, N. M. (2014). A Comparison of the Wellbeing of Orphans and Abandoned Children Ages 6-12 in Institutional and Community-Based Care Settings in 5 Less Wealthy Nations. Institutionalised Children Explorations and Beyond, vol.1:1, pp.78-101.

Dr. Aaqib Shahzad Alvi is Lecturer in the Department of Social Work, University of Sargodha, Pakistan.

Dr. Asif Naveed Ranjha is an Associate Professor in the Department of Social Work, The Islamia University of Bahawalpur, Pakistan.

Dr. Ibad Ullah Sajid is Social Welfare Officer in Social Welfare \& Bait ul Mall Department, Rawalpindi, Pakistan. 